\title{
Article \\ The Costs and Trade-Offs of Green Central Banking: A Framework for Analysis
}

\author{
Radu Simandan ${ }^{1, *}$ and Cristian Păun ${ }^{2}$ (D) \\ 1 Department of Economics, Polytechnic University of Bucharest, 060042 Bucharest, Romania \\ 2 Department of International Business and Economics, Bucharest University of Economics, \\ 010374 Bucharest, Romania; cristian.paun@rei.ase.ro \\ * Correspondence: radu.simandan@upb.ro
}

Citation: Șimandan, R.; Păun, C. The Costs and Trade-Offs of Green Central Banking: A Framework for Analysis. Energies 2021, 14, 5168. https://doi.org/10.3390/en14165168

Academic Editors: Philipp Bagus and José Antonio Peña-Ramos

Received: 28 July 2021

Accepted: 17 August 2021

Published: 21 August 2021

Publisher's Note: MDPI stays neutral with regard to jurisdictional claims in published maps and institutional affiliations.

Copyright: (c) 2021 by the authors. Licensee MDPI, Basel, Switzerland. This article is an open access article distributed under the terms and conditions of the Creative Commons Attribution (CC BY) license (https:// creativecommons.org/licenses/by/ $4.0 /)$.

\begin{abstract}
The participation of central banks in the fight against climate change has recently been advanced in several academic articles and policy papers. Since the emerging consensus is that climate change poses financial risks, the envisaged green central banking has a responsibility to address environmental sustainability as a means of promoting financial stability-an increasingly accepted goal of central banks in the post-financial crisis world. Thus far, the pro side of the argument is well represented in the literature, though often the benefits remain implicit: with the help of central banks via monetary and macroprudential policies, a smooth transition to a low-carbon economy would be somehow beneficial to all of us. With this article, we aim to add to this literature by looking at the costs and trade-offs of this course of action in light of the observation that the con side of the proposal has been only marginally addressed. We put forward a framework for the analysis of the costs and trade-offs of green central banking and exemplify the applicability of this framework by studying three cases of central banks for which the transition to green operation has been advanced. We find evidence that if costs and trade-offs are taken into account, the case in favor of greening central banks becomes less straightforward than is currently conveyed in the literature.
\end{abstract}

Keywords: central banking; green central banking; green finance; carbon dependability

\section{Introduction}

The involvement of central banks in the fight against climate change has been increasingly advocated in recent times. The first set of arguments supporting this request states that climate change affects how central banks design and carry out their core responsibility: monetary policy. Evermore severe and unpredictable climate-related shocks erode central bank policy space and complicate the traditional inflation-output trade-off. The second reasoning relates to the task of central banks to ensure macroeconomic financial stability and to the presumed systemic nature of climate-originated economic risks. Beyond this reactive stance of central banks, a proactive strategy is ever more suggested: central banks should take the lead in promoting a green economy, ensuring a smooth transition towards the low-carbon economic and social reality.

A cursory overview of recent policy papers and popular press articles on this topic reveals that many author stake for granted the merits of this policy shift. Similarly, the academic literature seems to display a heartfelt enthusiasm for this unprecedented transformation of central banking. The benefits of green central banking are usually presented in general terms, the quasi-moral responsibility of central bankers to align with the new culture of environmental sustainability is sometimes alluded to, while the costs and tradeoffs of this initiative are only marginally addressed. However, a review of the literature is necessary at this point to substantiate these claims, all the more so as the literature is showing signs of settling along certain lines of reasoning. This paper aims to address these gaps in the literature and to pave the way for a debate informed by an analysis of both the benefits and costs of following this route to sustainability. 
The article is structured as follows: in the next section, we critically review the literature that advances the idea of green central banking and provide more details on our research objectives, while in Section 3 we present an overview of the research methods employed to achieve these objectives. Section 4 provides the elements of an analytical framework for studying the costs and trade-offs of greening the central banks and exemplifies the applicability of this framework by using it to analyze the cases of three countries that are at various stages in their central bank greening strategies. Section 5 takes a closer look at the usefulness of the framework and describes a set of issues that need investigation to better frame the debate, while the last section concludes.

\section{Critical Literature Review and Research Objectives}

\subsection{Literature Review: Disregarding the Costs of Going Green}

Calls for greening central banking often stem from the observation that one of the most pressing problems facing the world today is environmental risk. As the argument goes, the environmentally unsustainable economic output that is the norm in the presentday economy could translate into risks that jeopardize the sustainability and stability of the financial system. Given that central banks are entrusted with the power to mitigate monetary and financial risks, the responsibility of central banks to address (anthropogenic) climate change is presented as an indisputable part of their mission.

A consensus can be identified in the literature dealing with green central banking: a set of conditions makes today's global economy unlikely to make significant progress toward sustainability if left to its own devices. Operating in a relatively deregulated economy, the private sector is the main generator of environmental risks and bears most of the responsibility for addressing them [1]. This is portrayed as a textbook case of market failure: if they are not forced to account for the damage caused to the environment, free markets will lead to overproduction and the accumulation of environmental risks [2,3]. Therefore, it is the unquestionable responsibility of the government to intervene and rectify these failures. New, bolder measures are required, as previous, less radical, attempts to correct the market failure, such as carbon trading schemes, have been disappointing due to the (excessive) autonomy of the private banking sector in allocating credit [4] and the resistance from "vested interests" [5]. Once the legitimacy of government action is established, the involvement of central banks can be advocated in terms of contributing their fair share to promoting the public interest: central banks are public institutions, a true extension of the government, with a duty to support broader public objectives-as opposed to the more recent and unsatisfactory phenomenon of pursuing narrow, price-related mandates $[5,6]$.

A more specific set of arguments is presented in the context of market failure: given their role as guardians of financial stability, central banks are responsible for addressing all risks that threaten the financial health of the country. The literature advances two main channels through which environmental risks translate into financial risks, usually dubbed as the physical risks channel and the transition risks channel [7]. Climate change causes floods and droughts that can affect food and energy prices, bringing about inflation spikes [3]. Liability risks may also arise, as companies affected by damages caused by climatic and environmental factors may seek compensations, creating major problems for the insurance industry [8]. The second channel is the result of the ongoing adjustment to a low-carbon economy. For instance, the current objective of meeting certain carbon emission targets limits the amount of fossil fuel that can be burned, the exploitation of these resources becomes economically unviable, the value of oil, gas, and coal mining companies is reduced, which in turn can impact the stability of financial firms exposed to these fossil fuel firms [9]. It is believed that these channels are high capacity since the financial risk resulting from climate change is regarded as "substantial" [10] (p. 12), "considerable" [3] (p. 10), and "major" [5] (p. 6).Climate-related risks may build up to reach systemic proportions and trigger the next large-scale financial crisis [11]. Along this line of reasoning, environmental challenges provide a good reason for central bank involvement 
even within the current mandate that authorizes central banks to safeguard macro-level financial stability.

However, a well-known set of problems and biases is likely to render this accommodative reform strategy ineffective. Central bankers may not recognize the direct link between environmental and financial risks and constant political pressure may be required (the knowledge problem), action may be delayed and environmental risks would accumulate (the inaction bias or institutional inertia), and the short-term monetary stability considerations could prevail over environmental sustainability (central bank short-termism). Therefore, this strategy is a short-term palliative; bold political steps are necessary to amend the current mandate [5,10], especially given that only 16central banks around the world have an explicit objective to promote or support "sustainable" economic growth or development [12]. This can be achieved either by including among the goals of central banks the explicit requirement to pursue a distinct environmental objective or by mandating central banks to support the government's economic policy in implementing sustainability programs.

To summarize the discussion related to the reasons for implementing green financial policies, the literature suggests a two-way approach: the environment must be protected from financial challenges, but at the same time, financial stability needs to be sheltered from climate-related risks. The first objective is met through the launch of promotional policies, while the second necessitates the use of prudential policies-central banks being well equipped to act on both fronts [13].

A wide variety of policy instruments has been advanced for the use of green central banks. In the context of the prime responsibility of central banks-devising and implementing monetary policy - green monetary authorities would be required to reorient their approach from short-term liquidity management to supporting the long-term sustainability agenda. They should review their collateral policy to include green assets while ensuring low and stable inflation as a precondition for sustainable growth [1]. Central banks are also advised to issue polymer banknotes that can be easily recycled instead of paper banknotes [1]. They also need to restructure their quantitative easing interventions in favor of buying green corporate and sovereign assets, especially considering that these programs have likely been detrimental to the climate, in part due to the choice of central banks that show a "carbon-intensive bias" [14] that perpetuates the current "carbon lock-in" [15]. For example, corporate bonds of companies in energy-intensive sectors constituted the base of the majority of Bank of England's corporate bond-purchasing program [10].

The case for implementing a green macroprudential regulatory framework is equally straightforward, although policymakers need to address some issues at the design stage. After delineating and conducting climate stress tests, central banks, in their capacity as financial supervisors, should activate several supervisory instruments such as imposing on commercial banks 'exposure rules to investments in carbon-intensive assets and assigning these assets higher risks weights in the capital adequacy framework $[3,4,16]$. The problem of the lack of a definition of green assets may hider this process, but steps have already been taken to remedy it; in addition, the risk-based weights currently in place in the Basel system may work as well for green lending [1]. In any case, increasing capital requirements for "brown" assets should be preferred over lowering capital requirements on loans to climate-friendly investments, given that lower capital increases risks to macroeconomic shocks, and even green assets can still be risky [10]. Improved financial disclosure via mandatory guidelines to address the information gap that investors face is undoubtedly a good thing, but given the short-termism and self-interest that markets promote, bolder steps are needed $[5,10]$.

A green central bank should not shy away from influencing credit allocation to promote green investments and thus penalize traditional, carbon-based industries. Lower reserve requirements have been advocated for banks exhibiting green portfolios, as well as the adjustment of capital requirements to reduce the risk assigned to green activities $[3,4]$. Green credit allocation should be promoted through targeted refinancing lines for commer- 
cial banks if secondary markets are undersized and mandatory credit quotas should be imposed on commercial banks to finance certain green assets, industries, or geographical areas [17]. Sectors declared as environmental priorities should also be the target of direct credit policy instruments, such as subsidized loan rates and differentiated discount ratescentral banks taking responsibility for incentivizing commercial banks to support green sectors through lower rediscount rates [3]. The link between the control of credit allocation imposed by the People's Bank of China and the growth of the Chinese economy is cited as an example of the merits of this policy [5].

To be fair, some articles in our database of sources briefly mention the downside of greening central bank activities. The costs and trade-offs of this policy shift are addressed in a few cases. The limitations imposed by the current mandate, and the danger of "overstretching" the mandate by including climate-related objectives, are mentioned but are often seen more as temporary institutional obstacles, easily overcome by changes in legislation $[12,15,18]$. Or, easier still, the existing mandate would not require alteration if climate change factors were seen as posing direct risks to the financial sector in an environment where central banks have a responsibility to promote financial stability [1,5]. If an additional environmental objective is included in the mandate, the constraint of the Tinbergen rule-according to which the number of policy goals should not exceed the number of policy instruments-is discussed $[3,18]$. A political-economy argument has also found its way into the discussion: there is a danger that unelected officials are being given too much power $[3,12]$. The emergence of trade-off relations between promoting environmental sustainability and traditional objectives such as monetary and financial stability is advanced, but this conflict seems to be seen as minor and distant since delays in implementation are not considered necessary and solutions are not offered $[1,12,15]$.

Some sources in our database recognize the importance and associated costs of coordination between the green monetary authority and other authorities with similar responsibilities. However, the literature tends to underestimate this challenge and to consider that it can be overcome through legislative clarification. The mandatory provision for central banks to coordinate with fiscal authorities does not necessarily imply a loss of central bank independence [6]. The current lack of coordination between the different agencies with environmental responsibilities is universally recognized and criticized $[1,5,18]$, and a coordinating role for central banks is suggested [11]. Several sources express the idea that the greening of central banks is still in its early stages [11,12], but the limited policy knowledge that results from this does not appear to suggest a careful approach, as advocates of green central banking show absolute confidence in this policy shift.

It should be noted that in all of these sources the costs and trade-offs are briefly and broadly discussed after the positive contributions have been emphasized and the intended use of various policy instruments has been presented in detail. The consideration of costs and trade-offs does not appear to cast any doubt on the appropriateness of the greening initiative. As side notes, even the word choice and writing style found in both academic articles and policy analysis papers seem to indicate an a priori preference for this policy. The use of emotionally laden terms is common practice: we are facing a "climate and ecological breakdown" [6] (pp. 4, 8), climate-related risks are "potentially extremely financially disruptive" [11] (p. iii), while "resisting the low carbon financial revolution is irrational" [2] (p. 2). A logical fallacy was also identified: in an apparent case of false equivalence, the way central banks have reacted to the COVID crisis (an unprecedented, one-time shock) is presented as a good example to follow for the case of climate-related risks (that materialize over several decades) $[6,19]$.

The green central banking policy turn has been also advanced for developing countries. Several particularities make these economies outstandingly relevant to the proposal. Given their expertise and weak competition from other regulators, central banks in developing economies are sophisticated and powerful players in their respective local settings; their participation in different transnational networks makes them prone to agree to rapid best practice transfer [3]. The need for action is greater in these economies since they are the 
ones that face the most urgent risks such as severe weather events caused by climate change [20]. Developing economies diverge largely from the central banking best practice framework. For example, they exercise greater state control over the allocation of credit. Given that various forms of credit control have been proposed as green monetary policy instruments, countries that already use these instruments are more likely to use them successfully [4]. Furthermore, the institutional environment appears to be favorable, as support for sustainable development and assistance to the government in implementing its policy agenda are often within the mandate of central banks [20]. Due to all these conditions, central banks in developing economies have been quick to accept important roles in mitigating the financial risks posed by climate change.

Although the idea of committing central banks to climate-related objectives is fresh and concrete steps in this direction have only recently been publicly discussed, a methodology has already been devised to numerically assess and rank central banks according to their progress on the green path [6]. In perfect harmony with the radical tone of the requests for the redesign of all public policies in the age of global warming, one category of indicators used to construct the scorecard is labeled Research and Advocacy, while another is titled Leading by Example. According to this methodology, China is the most advanced among the G20 countries in implementing green monetary and financial policies, closely followed by Brazil and France-although all countries are criticized for failing to match words with action.

Central bankers seem to have received these groundbreaking suggestions with less than enthusiastic interest. This resistance is attributed to the overly conservative stance of central bank leaders-reluctance to take actions to achieve goals that are not explicitly stated in their mandate, exaggerated concern for the inflation-related objective, underestimation of the (re)distributional consequence of monetary policy - and a hope that a new generation of central bankers will be more daring in this direction is expressed [21]. Therefore, reforming the mandate of central banks to include clear targets to support the transition to a lowcarbon economy is presented as the best way to deal with old-school central bankers [10]. However, the latest developments appear to support the argument that central bankers are beginning to change their views and accept their role in the transformation of monetary policy for the greater good [6]. The success of the Network of Central Banks and Supervisors for Greening the Financial System (NGFS) in winning the support of 90 central banks and financial regulatory agencies around the world is cited in support of this claim [6,22]. What at first seemed a doomed effort due to the foreseeable unwillingness of the technocrats inhabiting "capitalist central banks" to surrender to democratic control is now a promising way forward [19].

Greening central banking is not the only recent call to assign new tasks to (and provide new tools for) central banks. It is merely the latest suggestion in the long list of unconventional monetary policy proposals that gained additional momentum with every crisis in the last two decades - the financial crisis of 2009, the eurozone debt crisis of 2012, the Brexit referendum, and, finally, the COVID-19 pandemic of 2020. Some proposals of this sort deserve further investigation to help understand the ideational context of the green central banking proposal.

Rather than taking the convoluted path of lowering interest rates and reducing the cost of borrowing hoping to stimulate the economy through increased spending, central banks should give money directly to the people, preferably targeting a certain percentage of the poorest households in terms of income [23]. Given that today's monetary elite has disconnected from the legitimate concerns of the people, the mandate of central banks must be broadened to include the explicit objective of reducing the level of (income) inequality, a proposition supported by the criticism that monetary authorities have contributed to exacerbating inequality through expansionary policies implemented in the wake of the financial crisis of 2009 [24]. Indeed, inequality and climate change are sometimes analyzed together as potential on-contradictory objectives of central banks if carefully integrated into a new, wider monetary policy framework (e.g., [21]). 
Arguably, what these policy proposals have in common, in addition to their novelty, is their pro-inflationary nature on the one hand, and their intended distributional consequences on the other. If an innovative monetary policy can stimulate the economy in the short run, the danger of inflation over the long run does not seem to be a cause for concern. Furthermore, a monetary policy innovation appears to gain additional support among commentators if it results in the transfer of wealth and income from the rich to the poor.

Even before the financial crisis of 2009, central banks faced harsh criticism for failing to contribute to economic development, and calls for an extension of the mandate to include new objectives abounded. Since the then (and still) current "neoliberal" approach to central banking, obsessed with independence and narrowly focused on fighting inflation through the use of indirect tools, was deemed obsolete, a new framework was advanced to allow central banks to promote economic development using direct methods such as government financing, exchange rates management and implementation of sectoral policies [25]. Surely, not just any kind of economic development would do: only sustainable development should be the target of central banks in this reimagined framework, passing through some intermediate goals such as financial inclusion, access to agricultural finance, and support to small and medium-sized enterprises [26]. More recently, the notion that the U.S. Federal Reserve should be compelled to address racial inequality through its monetary and regulatory policies by amending its statute has found its way into the political debate [27]. At this point, it is safe to suggest that these discussions of how best to commit central banks to adapt to new realities served as the fertile ground on which the green central bank proposal flourished.

The analysis of the nascent academic and policy-analysis literature reveals that the proponents of the green central bank template show some intriguing inconsistencies and lack of substance, a fact that makes the development of a costs and trade-offs framework all the more necessary. For instance, the authors who criticize central banks for engaging in operations that have distributional consequences are also those who recommend the launch of green central banking - a policy change with clear and sometimes intended distributional consequences [21,24]. This suggests that what these authors criticize is not the idea of redistribution via central banks, but a particular distribution that is taking place and that for unstated reasons they consider unsatisfactory. Similarly, many authors who criticize central bankers for their resistance to change are pleased to entrust them with enacting a set of climate policies without an exit strategy $[19,21]$. This suggests that what these authors criticize is not the idea of resistance to change, but resistance to a particular change, which they consider essential for the current reality. Furthermore, the authors who rely on market failure theory as the basis for their recommendation to implement green central banking (virtually all authors in our database) fall short to recognize that today's (limited) market economy is far from being free from government interferences, including policies that aim to support sustainability. Indeed, this system operates under several framework conditions such as energy policy (government provisions related to the production, distribution, and consumption of energy), waste management policy (national frameworks imposed by the government for waste and resource recovery), and circular economy policy (aimed at carbon capture and storage), which are politically predetermined and may contribute to the insufficiently sustainable economy we experience today. Therefore, what at first glance appears to be a market failure can be better classified as a government (or regulatory) failure.

The filiation of this latest proposal aside, the question of how the greening of central banks would ultimately yield net benefits has received surprisingly little attention from academics and policy commentators. As a rule, academic articles, policy analysis papers, and popular press pieces begin by broadly discussing the dangers of climate change and the benefits of a green economy, present the involvement of the central bank as a desideratum, and go on to describe the redesigned central bank mandate and the policy tools to be used, while the foreseen benefits often remain unspecified. Typically, the costs of these policy actions are nowhere to be found in these analyses, while some trade-offs are only 
summarily sketched. Therefore, the question of why this policy avenue should be taken remains to this point largely unaddressed. This article is an attempt to help fill this gap and pave the way for a cost-benefit analysis of engaging in the greening of central banks.

In the next subsection, we look at a series of recent comments in the popular press that present a more realistic analysis by considering not only the benefits but also the costs and trade-offs of greening central banking.

\subsection{The Popular-Press Case for Considering the Costs and Trade-Offs of Going Green}

A critical view of calls for green central banks has recently begun to feature in popular press articles and blog posts. What distinguishes these sources from the scholarly articles analyzed above is a discussion of the downsides of a policy proposal that is otherwise full of bright, unquestioned, if sometimes only implicit, promises. While the potential contribution of central banks to tackling climate change is in principle viewed in positive terms, unwarranted ambition in this direction is considered dangerous. Central banks lack a clear mandate to engage in climate policy and expanding their traditional goals to make this possible would interfere with the process of democratic accountability [28]. Furthermore, the current route is superior: a carbon tax does not vary with the business cycle, whereas central banks aim to stimulate (or moderate) economic growth and therefore depend on the phases of the cycle [28]. The danger of engaging in a slippery slope of interventions is also suggested, as many other policy areas would benefit from the powerful involvement of the central bank [29]. To avoid another danger-compromising their primary price-stability objective-green central banks must have the discretion to forgo any program of sustaining the greening of the economy [30]. Given that what constitutes a "green" economic activity is not easy to define and would ultimately require the input of politicians, the politicization of central banking is another cost to consider, as is the central banks' mission creep-the inevitable result of broadening the mandate of central banks to accommodate the goal of greening the economy [31-33]. In the context of central banking, mission creep is the illegitimate attempt to dilute the focus on price stability by including new objectives best followed by different policy actors. The adoption of targets related to the green economy is the latest example of central bank mission creep.

The first of its kind, a recent book chapter adds to the view expressed in the popular press that doubts the usefulness of assigning central banks the leading role in mitigating the risks of climate change [34]. Several reasons are cited that make this move ineffective or even harmful: central banks do not have the authority to regulate the industries that harm the environment or the ability to affect these industries via monetary or macroprudential policies; financial institutions that the central bank does regulate impact the environment only indirectly; climate targets are not yet included in the statutes of central banks. Instead, given their power to tax and to redirect funds, to create special-purpose agencies, and to engage in international negotiation and persuasion, politicians are in a far better position to address these risks [34].

To conclude, we have argued in this subsection that the less enthusiastic view expressed primarily in opinion pieces is the result of an attempt to weigh the case in favor of central bank greening put forward in academic literature and policy papers by pointing out a set of costs and trade-offs associated with this policy adventure. These few sources make a tentative case against this radical transformation of monetary and macroprudential policies.

\subsection{Research Objectives}

We have argued above that the case in favor of greening central banks abundantly present in the literature is not rooted in a cost-benefit analysis of taking this course of action over others. Costs and trade-offs, in particular, have received little attention in academic research and only a few popular press articles considered them briefly. This observation is surprising given the general enthusiasm for this transformation reflected in academic articles and policy analysis papers. An analytical framework for identifying and evaluating 
these costs and trade-offs can provide a necessary tool for analysis and decision that can also find its way into policy debates. In this article, we begin to build this framework.

After advancing a framework to analyze the costs and trade-offs of going green, we investigate the applicability of the framework through the discussion of three case studies of countries that have begun to adopt or have declared their intention to adopt policies to green their central banks soon. The objective is to present a qualitative assessment of the costs and trade-offs that these countries would face if they followed through with their intentions.

\section{Overview of the Research Methods}

We have conducted a preliminary literature search on Google and Google Scholar indexed documents using the phrase green central banking within quotation marks, which yielded a relatively small number of sources on both search engines. We have selected the most relevant and significant sources concerning our topic, prioritizing those sources that explicitly touch upon the benefits, costs, and trade-offs of green central banking. We have thus arrived at 30sources, including eight academic articles and book chapters, 15 policy analysis papers, and seven popular press pieces. We have classified working papers as policy analysis papers. To discuss and evaluate these sources, acritical literature review approach [35] was preferred because our initial look at this literature revealed a stark contrast between the uncritical reception of the green central banking proposal among policy experts and commentators and the insufficient consideration given to the costs and trade-offs of this policy. To contextualize further, we have also reviewed some of the literature that assigns central banks a role in promoting economic development and the relatively recent suggestion that central banks perform "people" quantitative easing.

We have then considered the definition and qualities of analytical frameworks. These analytical tools aim to categorize the complex elements of a phenomenon to generate explanations or theoretical propositions [36]. Therefore, they are not mere reflections of reality, but instruments to make reality more accessible. Grounded in theory, they include observable implications that make them suitable for use in evaluating public policy alternatives. Analytical frameworks can help researchers to explain a phenomenon and policymakers to design better policies; they should be judged by their quality to reduce complexity and by their practical applicability to various contexts. Our analytical framework aims to clarify the nature of costs and trade-offs of going green in central banking, to classify these costs and trade-offs, and to offer a first approximation for different cases of central banking institutional frameworks.

\section{Results and Discussion}

To structure our analysis, we have used, as a theoretical framework, the body of insights that constitutes the political economy of central banking. The elements of the multidimensional institutional framework that constitute the best practice in central banking today have been used as the conceptual framework for our analysis. We then present how this institutional framework changes because of the implementation of the most common elements of the green central banking program. Unfavorable (or "negative") consequences for the central banking best practice framework are seen as representing the (opportunity) costs of going green in central banking.

\subsection{TheAnalytical Framework}

\subsubsection{The Template of Modern Central Banking}

The reality that most of today's central banks have evolved from private banks has puzzled many economists and policy commentators. Several key characteristics differentiate a central bank from other monetary institutions, public or private: a central bank serves as a banker's bank; it has a monopoly on the issuance of banknotes; acts as a lender of last resort; regulates commercial banks; conducts monetary policy [37]. Historically, each central government has granted these privileges to a particular private institution, turning 
it first into a "government-favored" private bank, then into a central bank-a specialized and autonomous government agency. The possession of these privileges makes central banks powerful players in today's economies. Given this authority and the fact that central bankers are not elected officials, the problem arises of how to regulate the exercise of this power according to the will of ordinary citizens. Framing the debate in terms of economic efficiency alone is not productive as higher-order ideals such as individual freedom and equality, and instruments such as the rule of law and the separation of powers are at work and set the limits of central bank action. The insights that central banking is best understood as part of the country's constitutional scaffolding $[38,39]$ and that the principles of the rule of law should apply to central bank actions even in extraordinary situations such as economic crises [40] can be used as the pillars of a theoretical framework to study the limits of the involvement of central banks in promoting a green economy.

Against the backdrop of the debate that followed these lines, a multidimensional framework evolved that is at work today in many advanced and developing economies. International financial institutions such as the International Monetary Fund (IMF) prescribe this institutional arrangement as the recipe for economic success. The pillars of this complex framework are: (1) central banks have clear and limited mandates; (2) central banks enjoy independence from different types of pressures; (3) central banks typically use indirect instruments to reach their goals [25,37,41,42]. An analysis of each of these areas-the elements of which constitute our conceptual framework-is presented below.

The primacy of the policy preferences of the voting citizen is a well-established principle of democratic policymaking. However, certain policy areas need insulation from the short-term orientation of political decision-making in a democracy. One increasingly popular way of dealing with political short-termism and lack of credible commitment is to delegate a policy area to independent agencies. Central banks are a typical example of independent agencies in today's economies. They have been entrusted with the authority to issue high-powered money and stabilize the economy via monetary policy. Given the fiat-money standard of today, the power that results from the exercise of this authority is considerable. This observation may give rise to legitimacy concerns, especially since central bankers cannot be voted out of office like elected officials. Likewise, assigning too many functions to central banks can erode their legitimacy as this may give central banks the power to choose from incompatible objectives. Various conditions for delegation have been proposed that legitimize the use of the (unelected) power of an independent agency. Among these, several are particularly relevant to central banking: the objective of the delegated policy can be specified; the preferences of the society are stable and concern a major social cost; there is a problem of committing to a policy regime; the policy instruments are expected to work; the agency would not have to face distributional choices; the legislature is able to oversee the activity of the agency [38] (Appendix of Ref. 38).

Since central banks exercise delegated coercive power, the limits of this power must be clearly stated in their mandate set forth through legislation. A central bank should not be free to set the goals for itself: doing so would be an excessively broad grant of power [42]. Similarly, central banks should not be free to reinterpret the terms of their limited mandate to pursue new, imperfectly defined objectives, as this may require additional instruments that if granted would probably go beyond delegated powers [42,43]. Adding new objectives via legislative initiatives is equally damaging to the central bank's legitimacy. The most common objective of central banks today spelled out in their mandate-price stability-has its origin in the desire to protect individual freedom and aims to constrain their monopoly power over the creation of paper money [37]. Implicit in this emphasis on price stability is the recommendation that central banks disregard other potential goals, such as promoting full employment or supporting certain industrial sectors, even if they become popular at some point with elected officials or ordinary citizens.

Several new threats to central bank legitimacy have been identified in recent years. The ad-hoc reinterpretation of central bank mandates that occurred in the wake of the financial crisis of 2009 to include safeguarding financial stability may erode their legitimacy, as 
central banks would require additional powers to pursue this fuzzy objective [43]. Another consequence of the crisis has been the launch of various forms of unconventional monetary policy, such as quantitative easing programs. Given that these programs have had serious distributive effects that exacerbated inequalities in income and wealth, the consequence for central banks-independent agencies that must refrain from making distributional decisions - has been an erosion of their legitimacy [44]. In this view, elected representatives should decide on issues that have important distributional effects. Surprisingly, some authors pointed out that central bank inaction in the face of the climate crisis has the same detrimental effect on legitimacy, as the goal of achieving sustainability has a proven "social usefulness" and central bank action would be grounded in the scientific consensus that climate change is costly [44].In this view, the social desirability of the end appears to justify the actions of central banks that would see their legitimacy reinforced in the eyes of the public.

The independence of central banks has been defended on similar grounds. In a constitutional democracy, the power to tax is reserved for the legislative branch. Since surprise inflation equates to taxation (on money holdings, in this case), the executive branch of government that controls the central bank would assume unconstitutional powers [38]. In practice, an independent central bank has the freedom to decide how to pursue its goals and its decisions are difficult to reverse for other centers of power [42]. In addition to being in harmony with higher-level principles such as the separation of powers, assigning independence to central banks is also an economically efficient arrangement. Monetary policy produces its effects on output and employment over a long time horizon. A sound monetary policy, especially if it is decided upon in the wake of an inflationary boom, has the profile of an investment decision: it implies assuming some costs over the short term and produces its positive effects over the long term. It is worth emphasizing, however, that the consensual prescription is that central banks should enjoy instrumental independence, but not goal independence: to ensure legitimacy, the objectives of the central bank must be established through a legislative process [42].

A useful distinction in this context is between de jure and de facto central bank independence. In practice, the legal framework may not reflect the true nature of the relations between politicians and central bankers as political pressure can be exerted unofficially. Indeed, in recent years, politicians have crossed the boundaries of the separation of powers in their relationship with central banks without legally restricting their de jure independence [45]. Another sign of politicization lies in motivation: if certain decisions are determined primarily by the desire to help a political actor, a central bank is acting beyond the remit of its mandate and is therefore becoming politicized [46]. In this line of argument, a given action by a central bank should not be considered politicized only because it has distributional consequences - the intention of the central bank to assist a political party must be tested to demonstrate the politicized nature of that action.

The case for central bank independence from day-to-day politics is well established in academic literature and public debate. A corollary of this principle is the need for the central bank to enjoy independence from public opinion. Assigning this type of independence is defended on similar grounds: it is very likely that the public has a short-time horizon and is unaware of the long lags in monetary policy. The public is, therefore, less likely to "invest" in disinflationary monetary policy. This is the rationale behind the recommendation to appoint a conservative central banker-that is, someone more averse to inflation than the public [47]. In a similar vein, we may consider a populist central banker as one who strictly follows social preferences related to the level of inflation, and an accommodating central banker as one who seeks political guidance related to the level of inflation to pursue.

With freedom comes responsibility: in the context of central banking, accountability is the reverse of the coin that has independence engraved on the obverse. Political accountability is the most basic form of responsibility for an independent agency such as the central bank created by the legislature via a process of delegation [38]. The financial crisis of 2009 prompted suggestions to rethink central bank accountability. In the face of uncertainty, 
central banks should strengthen their accountability by expanding their communication process to include discussions and deliberations with the public, reorienting their accountability efforts away from the financial industry towards the public and politicians, and even receiving new, more inclusive, and flexible objectives [48].

Since central banks announce their target in advance (the rate of inflation is the most common target today), the public may act on that target with certainty: if this is the case, the central bank is credible. Credibility is also important to central bankers, as they associate it with a lower cost of disinflation, a stable exchange rate, and greater public support for independence [49].

As independent agencies operating in constitutional democracies, central banks should not be mandated to make (big) distributional decisions or value judgments on behalf of society [38]. To help maintain their legitimacy, central banks have long emphasized the long-term neutrality of their operations: long-term real economic outcomes, such as the distribution of income and wealth, are largely unaffected by monetary policy [50] that can only affect the economy in the short term. The other side of this observation is that the short-run distributional nature of the monetary policy is widely accepted. The production of fiat money inherently creates winners and losers: the winners are those who get hold of the newly created money first, while the losers are those who receive the new money only after having to pay higher prices [51]. Faced with the obvious distributional consequences of their unconventional interventions implemented in the wake of the financial crisis of 2009, central banks have advanced the principle of market neutrality. The European Central Bank (ECB) implemented its public bond-buying program in such a way as to maintain the relative prices of these securities and guarantee a high degree of transparency, although it intended to affect the absolute prices of these instruments [52]. Following Tortola [46], we argue that the political nature of the distributional consequences of a central bank policy should be decided only after showing that the central bank targeted those consequences to help certain political actors.

As the current template prescribes, central banks must resist the temptation to use instruments of direct control, since they are incompatible with a free society on the one hand and can lead to misallocation of resources on the other. As instruments of monetary policy, direct controls allow central banks to instruct commercial banks regarding the type of loans they are expected to make, the level of interest rate they should charge or pay, etc. Many disadvantages of using direct controls have been identified. Credit controls, for instance, can deter competition and innovation in banking; they encourage the transfer of credit to areas that are not subject to control as rewards for doing so increase; they provide incentives for political corruption. The longer these controls remain, the more serious the inconveniences will be [41]. However, the longer the controls are used, the less likely they are to be abandoned, as their strategic shortcomings can be attributed to minor imperfections in design and implementation and a series of modifications follow-they tend to feed off their own flaws. These controls need continuous political reassessments as their design deficiencies risk becoming obvious to ordinary citizens [53].

The central banking template described above (which is summarized in Table 1), although consensually recommended by the academic community and international financial institutions, is not always and everywhere successfully implement. Indeed, the elements of this template can be understood as a set of tensions and challenges for elected and appointed officials, and for central banks themselves, which inevitably operate in a broader political, legal, and institutional environment. The limited mandate of central banks is designed to ensure their legitimacy; central banks further strengthen their legitimacy through transparency and accountability, striving to build credibility and reputation, and refraining from using instruments of direct control. 
Table 1. The traditional central banking template: tensions and challenges.

\begin{tabular}{ccc}
\hline Limited Mandate & Independence & Indirect Instruments \\
\hline Clear goals & Accountability & Short-term interest rate adjustments \\
Stable goals & Transparency & No state deficit financing \\
Legitimacy & Limited discretion & No credit controls \\
& Credibility & No interest rate controls \\
& Reputation & \\
\hline
\end{tabular}

Source: own representation.

\subsubsection{The Implications of the Green Proposal for the Central Banking Framework}

After reviewing the green central banking proposals found in the literature and describing the current central banking template, we now turn to the implications that this upgrade may have on how central banks act and how the public regards the mas players in today's democratic system of governance. Given the purpose of this research, we limit our analysis to the costs and trade-offs of this policy turn.

As we have noticed, various strategies have been suggested to incorporate green objectives into the mandate of central banks. If environmental risks were credibly presented as financial risks, central banks would be required to address these risks as part of their involvement in macroprudential policy. In addition to price stability, central banks may already have the secondary objective of supporting or promoting sustainability or sustainable development in their mandates. A different approach is necessary if the secondary objective is to support the government's economic objectives. Finally, new environmental goals can be added to the central bank's list of objectives through legislation.

The public perception that the central bank is acting beyond its mandate (or that it is rhetorically stretching the mandate to cover its actions) can open the way to the loss of legitimacy. Formally assigning multiple and possibly conflicting objectives can have the same consequence. The economic context may force the central bank to choose one macroeconomic objective to the detriment of others, a sort of power usually reserved for elected officials. If exercised by central banks, this power can become illegitimate in the public eye. This perception would be more acute if the power increased-a likely scenario since in the updated framework central banks implicitly exercise the power to select the environmental winners from the losers.

Illegitimate power is short-lived: the public would eventually voice their concerns to different governing bodies that would feel compelled to act. Clarifying the mandate through a legislative process may be one way to respond, but ad-hoc government pressure is another. Faced with unclear objectives, the central bank itself may be the one to seek the guidance of politicians. The stage is set for the loss of independence. As political priorities change, the central bank can become the scene of various political struggles. In response to such pressures, central banks may choose political allies to whom they grant favors-politicization is a consequence of the loss of independence. The principle of impartiality embedded in the definition of central bank independence would be broken. A politicized central bank may feel confident to take a stance on controversial issues such as the use of nuclear energy, but this would be far outside of the remit of central banks as we see them today. Even if the de jure independence did not change, the de facto central bank independence would deteriorate. Furthermore, the implementation of sectoral policies via central banks is inconceivable without the active contribution of elected officials.

Loss of reputation may be the consequence of the inability of central banks to meet unrealistic expectations. If central banks fail to deliver on sustainability issues, they may run the risk of being unable to meet the traditional objectives of their mandate, including price stability, as the central bank's credibility affects the expectations channel of monetary policy transmission. Having to choose the sustainability objective over the price-stability objective makes the central bank unwilling to fight inflation. However, the loss of reputation may render it unable to counter inflation via little credibility over inflationary expectations. 
Overstretching the mandate of central banks to include novel objectives that other policy actors can better pursue has its own set of drawbacks. This is where the ability of central banks to fulfill their sustainability expectations comes to the fore. Regardless of how central banks receive these new tasks (via changes in legislation or reinterpretation of the existing mandate), assuming unattainable objectives is a sign of mission creep. With the broadening of prerogatives come public exposure and criticism, along with an organizational response possibly in the form of a larger public relations budget and gradually more political nature of their operation. With new responsibilities comes the need for the central bank to coordinate its activity with other bodies that pursue related environmental objectives. Coordinating with the government poses the risks of fiscal dominance, loss of independence, and increased short-term orientation of monetary policy. As other authors have pointed out [18], the coordination costs incurred by central banks due to their environmental leadership role take the form of a more complicated decision-making process, impaired accountability, and a heightened inaction bias.

The threat of a slippery slope of interventions arises once we accept the central bank's involvement in promoting a green economy. If market failure is the theory on which central banks base their participation in the greening of the economy, the same argument is appropriate to solicit the input of central banks to correct all sorts of market imperfections, from monopolies to issues related to income distribution. Similarly, many economic shocks (such as medical emergencies) can translate into large-scale financial risks, but the contribution of central banks to address them directly (such as through the funding of medical research) is not yet suggested. Granted, slippery slope arguments should be used with care, as they can be nothing more than logically flawed rhetorical devices. To be credible, the mechanisms that produce the undesired phenomena described by the metaphor must be analyzed [54]. Adopting the categories from Volokh [54], we present two such mechanisms in the context of the green central banking proposal. An attitude-altering slippery slope could be facilitated by the time it takes for green central banking to show its effects. Regardless of the real causes of the progress towards a lowcarbon economy, the contributions of central banks can be presented as decisive. Given this supposed success, people might ask for greater involvement from central banks in promoting the most pressing goals of the moment, such as incentivizing investment at home rather than abroad or penalizing companies that pay "below market" wages. A political power slippery slope is also likely to manifest, as members of other industries that the central bank might support (the winners) have an incentive to spend on public advocacy campaigns to convince the public that their industries are just as virtuous as green-economy activities. Central banks may seek to expand their regulatory scope, since commercial banks that originate the loans to carbon-intensive industries may sell them off to investment institutions like pension funds. Central banks may also be tempted to monitor and regulate these industries. Expanding its scope is in the logic of every bureaucratic organization and the green turn may provide a good justification for central banks to do so. Therefore, the risk of an ever-expanding de jure or de facto central bank mandate is another downside of green central banking.

Central banks have been criticized for prioritizing price stability over other socially and economically desirable goals, such as promoting equality or development [24-26,44]. In this interpretation, a "low" level of inflation can be considered a small price to pay for achieving other goals deemed superior. In a similar vein, the suggestion in the nascent literature on green central banking seems to be that the goal of achieving a green economy should come before the goal of price stability. After all, "The role of the central bank is not carved in stone: it has changed through history" [5] (p. 4). Subject to interpretation, what constitutes price stability can also change, and the reinterpreted "low" level of inflation may include the price that the public must pay for a greener economy. One solution to this drawback is the classification of central bank objectives as primary and secondary. Indeed, besides the primary objective of maintaining price stability, many central banks have a secondary objective related to sustainability (usually introduced in the mandate with the 
phrase: "Without prejudice to the primary objective ... ") [12]. This solution, however, has the disadvantage of assigning central banks the discretion to choose between incompatible goals, a problem that can lead to loss of legitimacy.

The loss of independence and the ensuing politicization can also open the way to higher inflation. Avoiding the political bias in favor of inflation has been the rationale for assigning independent central banks the mission of regulating money. A large empirical literature has developed that demonstrates a statistically significant negative relation between central bank independence and inflation [55,56]. As we have shown previously, the increasing powerlessness of the green central bank over inflationary expectations due to its loss of reputation is another ingredient for higher inflation. An ideological reorientation of the monetary authorities is beginning to take shape, as central bankers appear ready to accept the primacy of the environmental objectives in their upgraded mandate. Redefining price stability to reflect the small price to pay (in the form of higher inflation) to reach the carbon neutrality target is just one pathway connecting this reorientation with the economy. Figure 1 shows how some inherent characteristics of the green central banking template can lead to higher inflation.

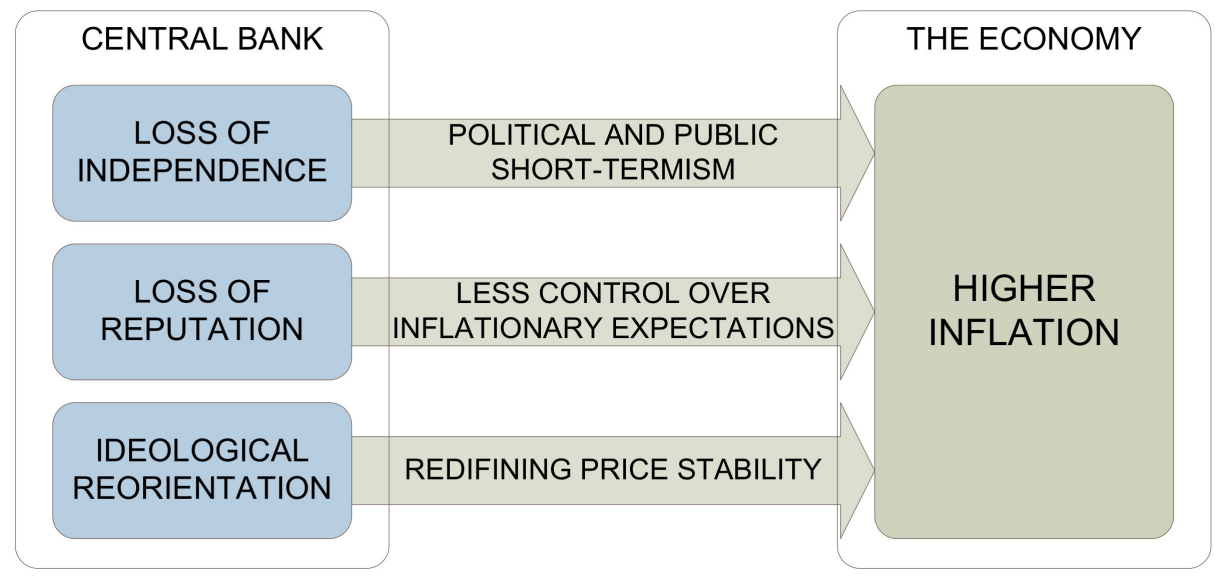

Figure 1. The inflationary consequences of green central banking.

Given that in the new framework, central banks would have the implicit power to choose the environmental winners from the losers, redistribution of income and wealth is an inevitable outcome. Central banks have attracted harsh criticism for the distributional consequences of their unconventional monetary interventions by authors leaning toward both ends of the political spectrum. On the one hand, they show that liquidity injections are likely to lead to investment in existing financial assets rather than production, a fact that tends to exacerbate inequalities by benefitting the privileged owners of these financial assets [24]. On the other hand, lower interest rates direct the new supply of money to the stock market, causing a fall in house prices and an increase in share prices, with a redistributive effect that benefitted the rich [57]. Nevertheless, the distributional effects of green central banking do not appear to weaken the support for the green policy turn. Indeed, it has been suggested that if redistribution via central banks aims to mitigate the risks of climate change and/or contributes to lessening inequalities of outcome-both of which are widely accepted social goals today - central banks may see their legitimacy increased as a consequence [44].

It is unclear, however, how central banks can contribute to reducing inequalities by engaging in eliminating funds for fossil fuel industries and providing subsidized funds for green projects. Political economy reasoning may suggest the opposite result, as wealthy, well-established, and well-connected players are more familiar with the political mechanisms that lead to the acceptance of a project as green. A difficult trade-off may emerge as central banks can fight climate change only at the expense of growing inequalities because wealthy players are more likely to receive the funds. The power to choose between 
these alternatives would add to their loss of legitimacy. As in the case of the carbon tax, compensations for losers can be devised, but this solution rests with politicians-central banks have no instruments to do so. Large-scale redistribution reinforces the case for a politicized central bank: the social preference for this policy can only be transmitted via the polls. Central banks would overstep their technocratic limits: the intention to assist political forces in implementing their vision of society replaces scientific considerations.

Traditional central banks have been criticized for their exaggerated interest in managing short-term demand fluctuations [1]. In the updated green template, central banks would be required to reorient their efforts away from dealing with short-term demand cycles to supporting long-term, supply-side growth. In this interpretation, the short-term demand fluctuations that translate into amplified output cycles are the elements of the opportunity cost of central bank support for sustainability. The mission of central banks in the green template is to incentivize and compel the transfer to a low-carbon economy and the use of various instruments devised for these purposes cannot vary according to the business cycle. Moreover, the excess supply of money and credit caused by the central bank's green reorientation may open up the vicious causal chain that links money creation to recessions, as described by the Austrian business cycle theory: lower interest rates drive up investments that cause an artificial business boom, entrepreneurial malinvestments would accumulate, while the subsequent recession has the merit of providing a necessary structural adjustment.

Green central banking can lead to the emergence of a bias related to the preferred policy toolkit. Economists have long observed that fiscal and monetary policies are to some extent substitutes: easy money policy can be temporarily compatible with low inflation if the state runs a large budget surplus [58]. Similarly, policymakers are tempted to use fiscal and monetary measures as temporary substitutes for more painful structural adjustments. Faced with the high cost of greening the economy (in the form of lost production), elected officials can transfer responsibility to an "independent" body of technocrats. A central banker has warned about this danger: "Central bank mandates have expanded-perhaps appropriately so-but there are limits to what monetary policy was designed to achieve. Central banks cannot be, and should not be regarded as, "the only game in town'" [59] (p. 1).

The inherent resistance to change in the central banking community has been presented as an impediment to the implementation of the green agenda [3,21]. The same central bank conservatism, however, can also manifest itself after the introduction of sustainability-related objectives into the central bank template. Not surprisingly at this early stage, the prospects of green central bank conservatism have not yet been analyzed. This hazard must be identified at the design stage in order to create institutional mechanisms to avoid it. The advocates of green central banking must answer difficult questions: is this policy shift temporary or permanent? When is the economy of a country (or a region, etc.) "green enough" that the input of central banks is no longer required? Accepting the fact that green central banking carries certain costs and trade-offs can open the way to address these issues. The reasons for this absence may have to do with the acceptance of central bank politicization among supporters of green central banking, as the suggestion appears to be that these tough issues will be addressed along the way via the political process $[19,21,24,25,44]$.

We have put together a final set of unfavorable implications under the heading "Ideas have consequences". The free exchange of ideas is the hallmark of a liberal society. Individuals are free to exchange not only goods and services but also ideas: as a result, a marketplace for ideas evolves. Similarly, economic policy ideas have consequences that go far beyond material considerations such as the distribution of income and wealth they promote. Every idea of economic policy promotes an ideal type of society and explicitly or implicitly suggests the best means of achieving it. The idea of a green central banking policy shift may convey the notion that any problem in today's society can be resolved if central banks are determined to intervene. This is a misguided view of what a central 
bank is and what it can achieve: "A central banking a democracy is not an all-purpose do-good agency, with authority to subsidize what it decides to be worthy, de-fund what it dislikes, and to force banks and companies to do the same" [32]. Together with their political allies, central banks would become promoters of a set of ideas that go far beyond their area of expertise: "The European Central Bank and other institutions are not just embarking on climate policy in general. They are embarking on the enforcement of one particular set of climate policies-policies to force banks and private companies to defund fossil fuel industries, even while alternatives are not available at scale, and to provide subsidized funding to an ill-defined set of 'green' projects" [31]. Witness to this debate, the public that tends to see the central bank as a branch of government (perhaps inspired by more sophisticated views that distrust the efficiency of institutional mechanisms such as the separation of powers and the independence of the central bank) would be tempted to accept as true the long-discredited idea that central planning is the ultimate means of curing the ills of society.

\subsubsection{A Taxonomy of Costs and Trade-Offs of Green Central Banking}

In light of the above discussion, we propose the following structure of the costs and trade-offs that the greening of central bank operations may have (Table 2). The Costs of going green category comprises the costs and trade-offs incurred in the phase of transition from the current to the green template of central banking. A loss of legitimacy and independence is expected, politicization would increase, we could witness a case of mission creep, and a slippery slope of central banks interventions might be set in motion. The Acting green category is made up of the possible results of using different instruments to sustain the green sector through the action of the central bank: price and financial instability, reinforced distributional effects, less countercyclical capacity, and an increased stop-go character of the monetary policy. The Staying green group aims to capture some policy biases that green monetary and macroprudential policies can introduce into the economic system.

Table 2. The reinterpreted central banking template: costs and trade-offs of green central banking.

\begin{tabular}{ccc}
\hline Going Green & Acting Green & Staying Green \\
\hline Loss of legitimacy & Price instability & Excessive reliance on monetary policy \\
Loss of independence & Loss of reputation & "Ideas have consequences" \\
Politicization & Distributional effects & \\
Mission creep & Less countercyclical capacity & \\
Slippery slope & & \\
\hline
\end{tabular}

Source: own representation.

No classification has been made according to the bearer of these costs: they may be internal (i.e., costs for the central bank) or external (e.g., costs for the economy). The set of costs and trade-offs should be understood as the opportunity cost of going green in central banking: all the forgone benefits of maintaining the current template-the sacrifices of going green. Of course, this taxonomy does not provide an exhaustive description of the costs and trade-offs of moving from the brown to the green template, rather it points out only the most obvious entries that a future cost-benefit analysis should contain in the Costs column. The discussion remains open: the list can be expanded as new policy objectives and instruments are added to the greening strategy.

\subsection{Case Studies}

Drawing on the framework of costs and trade-offs laid out in the previous section, we exemplify in this section the application of the analysis by examining the cases of three central banks that are at different points in their respective greening strategies. We have based our selection of cases on data availability, diversity, and their progress on the path to a green central bank. The quintessentially independent central bank, the ECB offers an interesting case of a central bank that is getting involved in promoting 
sustainability, communicating its intentions to go green, and publishing studies and policy papers detailing its plans. The case of Brazil is appealing because the country has a developing economy with a central bank that shows weak de jure independence, has made tremendous strides on the path to green central banking, and is vigorously publicizing its plans. Finally, the most familiar case to the authors, Romania has a central bank with little credibility that recently opened the discussion about greening its operation. However, since the central bank greening debate is universally in its infancy, these examples are hypothetical case studies: the costs and trade-offs will manifest as the greening strategy advances.

\subsubsection{The Euro Area}

Historically, the ECB has been considered one of the most independent central banks. The European Council appoints the President and the Executive Board members with a qualified majority for an 8-year non-renewable mandate. The decision is based on consultations with the European Parliament. The dismissal of these members is subject to special conditions and can only be done by the EU's Court of Justice (CJUE). According to the Treaty on the Functioning of the European Union (TFEU), the primary objective of the ECB is to maintain price stability in the euro area. The Treaty also mandates the ECB to follow the secondary objective of supporting EU economic policies without prejudice to the primary objective of price stability. The task of contributing to financial stability through prudential supervision assigned to the ECB in 2013 is subject to limitations arising from the primacy of the price stability objective [60].

The sovereign debt crisis of 2010 prompted the launch of several unconventional monetary policy operations that were subject to numerous unsuccessful legal challenges. The CJUE ruled that the program empowering the ECB to buy sovereign bonds issued by the national governments of the eurozone was in line with the EU Treaties (in 2015) and did not exceed the ECB's mandate (in 2016). The Federal Constitutional Court of Germany ruled in 2018 that the ECB's Public Sector Purchase Program (PSPP) launched in 2015 did not violate the prohibition of direct financing.

A de facto mandate broadening is expected with the implication of the ECB in promoting a green economy. The ECB has advanced several reasons for its willingness to be part of this process. First, the banking sector in the euro area is exposed to the risks of carbon-intensive industries and needs protection through financial supervision. Second, the ECB considers that it must reflect climate risks in its portfolio of securities. Third, the ECB needs to address environmental factors because they can affect price stability [61]. Environmental risks are exceptional circumstances requiring exceptional measures. The ECB's determination is obvious from how it unceremoniously abandoned the principle of market neutrality in the context of asset purchases. Originally, a self-imposed requirement to maintain the relative prices of securities was in place to limit the interventions, as the ECB considered that the price discovery mechanism for sovereign risk was sufficiently important not to be affected [52]. In the updated intervention logic, the ECB abandons these old-style restrictions, as it suspects that they promote the current carbon-intensive forms of production that pose environmental risks [62]. Subject to continued political support, the way is now clear for the ECB to become involved in promoting a low-carbon economy.

It is worth emphasizing that the ECB would not implement a climate policy of its choice. It would have to follow a particular climate policy agreed upon at the EU level through political negotiations [32]. This suggests an increased politicized course of action, as the ECB is shedding its technocratic façade to openly grant favors to elected officials-the condition for a politicized ECB advanced by Tortola [46] is therefore met. Each new crisis seems to justify a rethinking of the central bank's mandate. In what appears to be a public communication campaign to explain the envisaged shift in its policy, the ECB has used the COVID-19 pandemic as an example of a global disruption that requires the implication of central banks and as a precedent for the upcoming engagement to facilitate the transition to sustainability [63]. The abundance of policy objectives in a multinational currency 
union accentuates the danger of engaging in a slippery slope of mandate broadening and interventions, as many other policy areas qualify for ECB participation.

It has long been observed that a monetary union among sovereign states (such as the EMU) encourages international political conflict, as national economies are often at different points in their respective business cycles and therefore need different monetary policy interventions for stabilization [64]. A green ECB would introduce new points of contention due to the intrinsic distributional consequences of green central banking. As in the case of the EMU redistribution acts on sovereign nations, rather than on regions or industries, the national governments of the countries at the losing end would not hesitate to take this battle to the EU level. For example, a political conflict may result from the fact that the ECB is buying bonds from different countries at different prices. Reinforced EU-wide fiscal transfer schemes would be required to offset these consequences, but this solution depends on political negotiations. The competition among EMU members to control the ECB would become more acute given the higher stakes involved. Appointing the president of the ECB would be more difficult and issues related to climate policy would take priority in this decision. The acceptance criteria for green projects to be financed via the ECB would also be the result of political negotiations to ensure an equitable distribution of cost and benefits among member states. While EMU has been described as a system that aggregates conflict [65] due to the inherently redistributive consequences of money creation through the operation of the old-style, conservative ECB, a euro area managed by a green ECB would become even more contentious.

The new round of unconventional interventions through financing green projects will fuel long-term inflationary expectations and reduce public confidence in the ECB. The timing could not be more unfavorable: this further erosion of legitimacy comes shortly after a series of unconventional interventions that introduced various threats, such as a growing level of public mistrust, questioning of the political independence of central banks among the elite, and institutional overburdening [66].

\subsubsection{Brazil}

The Central Bank of Brazil (CBB) was established in 1964 as an independent federal body. The National Monetary Council (NMC), consisting of two members of the Executive (the Minister of Economy, who acts as chairperson, and the Special Secretary of Finance of the Ministry of Economy) and the Governor of the CBB, has the task of formulating the country's monetary and credit policy, aimed at promoting social and economic development [67]. The main objective of the NMC established by the law is to adjust the money supply to the "real" needs of the national economy and its development process; a price-related objective is also suggested, as the NMC is tasked with preventing and correcting inflationary or deflationary pressures [68]. Since early 1999, the CBB has been implementing a strategy of direct inflation targeting, the NMC setting the inflation target based on a consumer price index [69]. The adjustment of the monetary policy interest rate is the main instrument of monetary policy; the CBB's Monetary Policy Committee (MPC), comprised of the bank's Governor and the eight Deputy Governors, sets the target for the interest rate.

The constitution prohibits the central bank from directly or indirectly financing public authorities but, in some circumstances, the CBB can purchase government securities. The President of the state appoints the members of the MPC (i.e., the Governor and Deputy Governors), with the approval of the Senate. They are appointed without a specified duration of their mandate and can be removed at any time by the President without any argument or justification.

Analysts observed that the CBB has achieved high de facto operational independence based on a fragile foundation of low de jure independence, an institutional arrangement that poses risks of politicization [70]. In these circumstances, the institutional performance of the CBB has been relatively modest. After a period of hyperinflation, the introduction of the inflation-targeting regime led to a sharp decline in inflation. However, compared to the 
average for the world economy, the level of inflation in Brazil remained high, above the target by a substantial margin in 10years, and outside the tolerance interval in four years during the interval 1999-2015 [71]. Although in recent years there has been an improvement in the ability to keep inflation close to or below the target [70], setting relatively high target rates in the context of the world economy $(4.25 \%$ in $2019,4.00 \%$ in $2020,3.75 \%$ in 2021 ) raises serious concerns about the $\mathrm{CBB}^{\prime} \mathrm{s}$ institutional performance in accomplishing its price-stability objective.

The CBB has interpreted the broad formulation of its primary objective ("Adjusting the volume of the money supply to the real needs of the national economy and its development process", emphasis added, [68]) as providing the legal basis for engaging in promoting a green economy. Some recent actions of the CBB towards green economy are the following: (1) in 2017, mandatory disclosure of exposure to environmental risks was introduced for the capital adequacy calculation [72]; (2) in 2020, the CBB and the Climate Bonds Initiative sign a Memorandum of Understanding to promote a sustainable finance agenda and integrate socio-environmental and climatic risks in the national financial sector [73]; (3) in 2020, the CBB launches a sustainability agenda aimed at promoting a "more sustainable, dynamic and modern economy" as a means to achieve "a sustainable and inclusive growth" [74]; (4) as a result of these efforts, in 2020, the CBB receives the "stamp of approval": it becomes a member of the NGFS; (5) in 2021, the CBB opens public consultations to redefine sustainability criteria for rural credit granted by banks in compliance with various social and environmental parameters, such as overlap with indigenous areas, deforestations, slave-like labor conditions, low-carbon agriculture, the use of renewable energy sources [75]. As a result of these measures, policy analysts consider Brazil to be one of the greenest central banks in the world and rank it second after China [6].

The first observation related to the greening of the CBB is the apparent lack of debate on the legal basis for assuming green targets. Granted, the CBB charter lacks clarity in setting the objectives of the central bank, as it stipulates seven tasks that the NMC must follow. The legal requirement to prevent and correct "inflationary or deflationary surges of domestic or foreign origin" [68] has constituted the basis for the implementation of an inflation-targeting framework. The CBB's task of adjusting its money supply to contribute to the development process can be seen as a legal basis for implementing a sustainability agenda, as some observers do (e.g., [12]), but this can also be considered a case of mandate overstretching. Once sustainability made its way onto the menu, a plethora of different objectives may follow. Signs of mission creep are already visible in the way the CBB introduced the goal of "inclusive growth" into its sustainability agenda [74]. Given the country's history of hyperinflation and a modest level of central bank credibility, the CBB's control over inflationary expectations may diminish. A de facto abandonment of the inflation-targeting framework may also result from the implementation of a green agenda. The low level of legal protection against political pressures can also explain the rapid, politically-inspired advancement towards a green central bank and may add to the vicious cycle of loss of credibility, loss of influence on inflationary expectations, and inflation.

\subsubsection{Romania}

The National Bank of Romania (NBR) is governed by the Board of Directors, composed of four executive members (including the Governor) and five non-executive members, all appointed by the Romanian Parliament for a renewable 5-year term. Parliament has discretion over the removal of any member of the Board. The members of the Board cannot hold positions in the Government and the Government is not represented on the Board [76]. The NBR sets its monetary policy without the involvement of the Government or Parliament. The law requires the Governor to submit annual reports on the central bank's activity to Parliament, including the bank's audited financial statements. The NBR has a consultative role in budget procedures, collaborating directly with the Ministry of Public Finances in this regard. Exchange rate policy (currency regime, currency convertibility, foreign exchange market regulations, etc.) is the sole responsibility of the NBR. 
The legislation sets forth price stability as the fundamental objective of the NBR: "The primary objective of the National Bank of Romania shall be to ensure and maintain price stability" [76]. The NBR has the secondary objective of supporting the economic objectives of the Government: "Without prejudice to its primary objective of ensuring and maintaining price stability, the National Bank of Romania shall support the general economic policy of the State" [76]. However, the NBR has the last word in case of conflict between the objective of price stability and other objectives of the Executive and cannot request permission or subordinate the bank to the disposition or command of the government. In 2017, the NBR became an active and key member in the newly created National Committee for Macroprudential Oversight (NCMO), thus receiving a financial stability role. During NCMO Board meetings, the central bank can advance its analyses and make proposals regarding the macro-level financial stability. In 2020, the NBR joined the NGFS and took the first steps to design and use analysis tools to assess climate risks within the framework of the financial stability policy and to publish the results of this research in its financial stability reports.

Since August 2005, the NBR has been implementing a strategy of direct inflation targeting. In its public communication, the NBR emphasizes a set of preconditions that facilitated this monetary policy orientation: strengthened de jure independence as a result of a new NBR statute in July 2004; enhanced credibility and accountability; more effective communication with the public and markets; better understanding of macroeconomic behavior patterns and monetary policy transmission channels [77]. The main monetary policy instruments are open market operations, standing facilities, and reserve requirements. The NBR cannot buy financial instruments directly on the primary market. The law prohibits overdraft or direct credit facilities granted to any public entity, except state-owned credit institutions. The main interventions in the secondary markets are repo and reverse repo transactions, foreign exchange swaps, deposit-taking operations, collateralized credit operations. The credit facility with commercial banks is limited to 90 days. Only the central bank can set the terms of money market operations with treasury bills and bonds. There are no legal limitations on the volume of money market transactions with treasury bills and bonds purchased by commercial banks, but the NBR may establish specific limitations if necessary. Open market operations with commercial banks are based on a minimum interest rate.

Recently, the NBR opened the debate on the central bank's contribution to promoting a green economy. In a conference, the NBR Governor emphasized the consensus among EU leaders that the recovery from the COVID-19 crisis must be sustainable by placing green investments and digitalization at its core [78]. He also reviewed the most common ways central banks and financial regulators use to integrate climate factors into their activities: review bank stress tests to assess exposure to climate risk; revise the financial stability policy to include climate change risks; raise awareness about environmental risks and promote opportunities derived from the environmental agenda [78].

When analyzing post-pandemic recovery scenarios in 2020, the NBR seems to fully adhere to the concept of "green recovery" [62,79]. The strategy to implement this concept involves policy measures such as the development of "climate-smart" infrastructure and technologies, penalizing carbon-intensive investments, and subsidizing the transition to a low-carbon economy [80]. However, in 2021, the NBR has identified the implementation of green energy projects in the context of stimulus packages as a risk factor for its inflationary projections [81]. In 2020, the NCMO established a working group on green finance, which in its report recommends that the central bank create a dashboard to monitor climate-related risks for the banking sector, make more information on green lending public, as well as contribute to the development of the climate change governance architecture [82]. The committee also expressed concern that without a developed capital market and significant participation of the non-bank sector in the financing of the public and private sectors, the credit expansion induced by green financing may contribute to the accumulation of inflationary pressures [82]. What is lacking in this early stage of debate is a discussion on 
the legislative basis that legitimizes the central bank's participation in the greening of the economy.

The success of the inflation-targeting framework in Romania has been modest, as the monetary authority managed to reduce inflation in the early 2000s, but consistently missed the inflation target after 2007. The NBR has constantly attributed this failure to exogenous factors, such as the increase in the price of oil. However, a study shows that this reason is not reliable, since oil price shocks accounted only marginally for the component of inflation that includes volatile prices and did not have a significant influence on the core inflation [83]. Therefore, the responsibility for the above-the-target inflation rests with the monetary authority. In these circumstances, the credibility of the central bank has been low, positioning itself as one of the least credible monetary authorities operating under an inflation-targeting regime [84]. This modest institutional performance does not help the case for embarking on the greening of the Romanian central bank. The loss of reputation that may result from the lack of instruments to promote a green economy in a non-discretionary and non-contradictory manner is another factor that would erode the credibility of the NBR. This, in turn, would undermine the NBR's influence on inflationary expectations. The road to independence has been slow and difficult for the NBR. The politicized nature of central bank operations was commonplace for many years at the beginning of the transition. The public may penalize green politicization with an additional loss of credibility.

Furthermore, the purported advantages for emerging economies that support the implementation of green central banking appear weak in the case of Romania. The NBR does not use instruments of direct credit control. Unlike other emerging and developing economies where central banks have a broader mandate to support sustainable development [20], the NBR's mandate clearly points to price stability. Sure, the mandate can be expanded through legislative change to include clear environmental goals, but the public may see this as a mission creep. Following environmental goals without expanding the mandate can be seen as a sign of politicization and lead to loss of legitimacy. A less credible NBR is the result of any of these strategies.

\section{Conclusions and Directions for Future Research}

As climate change presents itself as a major challenge for all aspects of policymaking today, there is increasing advocacy for the involvement of central banks in mitigating the economic impact of environmental factors. Academics and analysts interested in the economic aspect of sustainability have a consensus of mistrust of the self-regulatory capacity of the market economy on environmental issues and consider that the private sector acting on market opportunities is perpetuating the current carbon-intensive economy. As a principle, they assume that the state has a responsibility to correct this market failure, while central banks, as extensions of the state, have a moral and sometimes legal obligation to assist in this important endeavor. In this view, central banks cannot avoid their participation, as climate change can lead to the accumulation of financial risks that affect financial stability at the macrolevel. Furthermore, with their unconventional interventions, central banks have helped maintain the existing carbon lock-in. The literature that deals with these issues is growing rapidly, but it appears that the nascent body of knowledge is missing important elements for the decision-making process. In particular, the disadvantages of central bank involvement in promoting a green economy lack academic debate and receive little attention in public discussions. This article is the first attempt to build a framework for the analysis of the costs and trade-offs of green central banking.

In attempting to construct the main elements of a framework for the analysis of the (opportunity) cost of greening the activity of central banks, we have taken as a theoretical framework the literature that views central banks as independent agencies that act within a constitutional structure that incorporates principles such as the rule of law and the separation of powers. On this background, we present the traditional template of central banking and analyze how the greening of central banks alters this template. 
A central bank that operates in a constitutional democracy has a limited mandate that establishes clear objectives that remain unchanged to ensure its legitimacy; is accountable to elected officials and enjoys operational independence from political and public pressure to contribute to its credibility and reputation; refrains from using instruments of direct control.

In the reimagined green framework, loss of legitimacy and independence, politicization, mission creep, and a slippery slope of interventions are expected. Price instability and higher inflation, loss of reputation, reinforced distributional effects, and a diminished countercyclical capacity are other elements of the price to pay for involving central banks in greening the economy. We also identify some biases that would be introduced in the economic system, such as over-reliance on the magic of money creation and commercial banking regulation (to the detriment of old-school structural or fiscal measures), the possible initiation of a new form of central bank conservatism, and the promotion of some misconceptions in the public debate. These suggestions are not entirely new: the literature identifies but does not fully analyze some of these drawbacks, and the prevailing support for the green central banking solution remains largely intact.

An implication of our analysis is the need for an emphasis on the importance of price stability as the primary objective of central banks. As we have tried to show in this article, price stability as a mandated objective of central banks is in harmony with higher principles such as the rule of law and individual freedom. Recognizing the challenges that threaten to hinder the preservation of such principles in the age of climate change, the danger of diluting this objective by adopting different vague and difficult-to-quantify objectives must also be acknowledged. In this sense, the debate on green central banking should address a key point: the compatibility of the new central banking framework with these higher principles.

Future research should be aimed at identifying the factors that influence the manifestation in different institutional settings of the costs and trade-offs that we have advanced here. Among these, we suggest the following: institutional quality (e.g., as reflected in the components of the Index of Economic Freedom), past inflationary experience, past central bank credibility, central bank communication, social trust, political instability, inflation aversion, political fragmentation, legal culture, the design of the political system. Studies show that these factors influence the level of independence of central banks. It is our contention that factors such as these influence the structure and level of the costs of greening central bank activity. The upcoming central bank legitimacy crisis that David J. Archer [43] has warned about deserves academic attention, and the envisaged green central banking policy turn provides the perfect opportunity for this investigation.

Author Contributions: Conceptualization, R.S. and C.P.; methodology, R.S.; formal analysis, R.Ș. and C.P.; investigation, C.P.; writing-original draft preparation, R.S.; writing-review and editing, C.P.; supervision, C.P. All authors have read and agreed to the published version of the manuscript.

Funding: This research received no external funding.

Institutional Review Board Statement: Not applicable.

Informed Consent Statement: Not applicable.

Data Availability Statement: Not applicable.

Acknowledgments: The authors would like to thank Silviu Cerna for his helpful comments and suggestions. The usual disclaimer applies.

Conflicts of Interest: The authors declare no conflict of interest.

\section{References}

1. Fisher, P.; Alexander, K. Climate Change: The Role for Central Banks. Data Analytics for Finance Macro Research Centre; Working Paper No. 2019/6; King's College London: London, UK, 2019.

2. Gunningham, N.A. Quiet revolution: Central banks, financial regulators, and climate finance. Sustainability 2020, $12,9596$. [CrossRef] 
3. Volz, U. On the role of central banks in enhancing green finance. In Design of a Sustainable Financial System; Inquiry Working Paper 17/01; UNEP, Inquiry: Nairobi, Kenya, February 2017.

4. Campiglio, E. Beyond carbon pricing: The role of banking and monetary policy in financing the transition to a low-carbon economy. Ecol. Econ. 2016, 121, 220-230. [CrossRef]

5. Van Lerven, F.; Ryan-Collins, J. Central Banks, Climate Change and the Transition to a Low Carbon Economy: A Policy Briefing; New Economics Foundation: London, UK, 2017; Available online: https://neweconomics.org/uploads/files/NEF_BRIEFING_ CENTRAL-BANKS-CLIMATE_E.pdf (accessed on 12 July 2021).

6. Barmes, D.; Livingstone, Z. The Green Central banking scorecard: How green are G20 central banks and financial supervisors? Positive Money: London, UK, 2021; Available online: https:/ / positivemoney.org/publications/green-central-banking-scorecard (accessed on 12 July 2021).

7. Grippa, P.; Schmittmann, J.; Suntheim, F. Climate change and financial risk. Fin. Dev. 2019, 56, 26-29.

8. The Impact of Climate Change on the UK Insurance Sector. A Climate Change Adaptation Report by the Prudential Regulation Authority; Bank of England: London, UK, 2015.

9. Schoenmaker, D.; Tilburg, R.V. What role for financial supervisors in addressing environmental risks? Comp. Econ. Stud. 2016, 58, 317-334. [CrossRef]

10. Macquarie, R.A.; Green Bank of England. Central banking for a low-carbon economy. Posit. Money 2018. Available online: https:/ / bit.ly/3e0E4Cb (accessed on 12 July 2021).

11. Bolton, P.; Despress, M.; da Silva, L.A.P.; Samama, F.; Svartzman, R. The Green Swan-Central Banking and Financial Stability in the Age of Climate Change, Bank for International Settlements.Banque de France Eurosystème. 2020. Available online: https:/ / bit.ly/3vtzNgj (accessed on 12 July 2021).

12. Dikau, S.; Volz, U. Central bank mandates, sustainability objectives and the promotion of green finance. Ecol. Econ. 2021, 184, 107022. [CrossRef]

13. Baer, M.; Campiglio, E.; Deyris, J. It Takes Two to Dance: Institutional Dynamics and Climate-Related Financial Policies. 2021. Available online: https: / / ssrn.com/abstract=3862256 (accessed on 12 July 2021).

14. Monnin, P. Central banks and the transition to a low-carbon economy. Counc. Econ. Policies Discuss. Note 2018, 2018, 1. [CrossRef]

15. Campiglio, E.; Dafermos, Y.; Monnin, P.; Ryan-Collins, J.; Schotten, G.; Tanaka, M. Finance and climate change: What role for central banks and financial regulators. Nat. Clim. Chang. 2018, 8, 462-468. [CrossRef]

16. Schoenmaker, D. Greening monetary policy. Clim. Pol. 2021, 21, 581-592. [CrossRef]

17. Dikau, S.; Volz, U. Central Banking, Climate Change and Green Finance; ADBI Working Paper Series No. 867; Asian Development Bank Institute: Tokyo, Japan, 2018.

18. D'Orazio, P.; Popoyan, L. Taking up the Climate Change Challenge: A New Perspective on Central Banking; LEM Working Paper Series, No. 2020/19; ScuolaSuperioreSant'Anna; Laboratory of Economics and Management (LEM): Pisa, Italy, 2020.

19. Langley, P.; Morris, J.H. Central banks: Climate governors of last resort? EPA Econ. Space 2020, 52, 1471-1479. [CrossRef]

20. Dikau, S.; Ryan-Collins, J. Green Central Banking in Emerging Market and Developing Country Economies; New Economics Foundation: London, UK, 2017; Available online: http://neweconomics.org/wp-content/uploads/2017/10/Green-Central-Banking.pdf (accessed on 19 July 2021).

21. Honohan, P. Should Monetary Policy Take Inequality and Climate Change into Account; Peterson Institute for International Economics Working Paper: Washington, DC, USA, 2019.

22. NGFS, Annual Report. 2020. Available online: https://www.ngfs.net/sites/default/files/medias/documents/ngfs_annual_ report_2020.pdf (accessed on 19 July 2021).

23. Blyth, M.; Lonergan, E. Print less but transfer more: Why central banks should give money directly to the people. Foreign Aff. 2014, 93, 98-109.

24. Dietsch, P.; Claveau, F.; Fontan, C. Do Central Banks Serve the People? Polity Press: Cambridge, UK; Medford, MA, USA, 2018.

25. Epstein, G. Central Banks as Agents of Economic Development; WIDER Research Paper: 2006. Available online: https://www. econstor.eu/handle/10419/63574 (accessed on 19 July 2021).

26. Dafe, F.; Volz, U. Financing Global Development: The Role of Central Banks; Briefing Paper; German Development Institute/Deutsches Institutfür Entwicklungspolitik (DIE): Bonn, Germany, 2015; Volume 8.

27. Politi, J. Joe Biden vows to push Fed on economic racial inequality. Financial Times, 28 July 2020.

28. Green envy. The rights and wrongs of central-bank greenery. The Economist, 14 December 2019.

29. Gross, D. The Dangerous Allure of Green Central Banking, Project Syndicate. 18 December 2020. Available online: https: / / bit.ly / 2PytXuS (accessed on 16 May 2021).

30. Brunnermeier, M.K.; Landau, J.-P. Central banks and climate change. Available online: https://voxeu.org/article/central-banksand-climate-change (accessed on 16 May 2021).

31. Cochrane, J.H. Central Banks and Climate: A Case of Mission Creep; Hoover Institution: Stanford, CA, USA, 13 November 2020; Available online: https://www.hoover.org/research/central-banks-and-climate-case-mission-creep (accessed on 5 June 2021).

32. Cochrane, J.H. Challenges for Central Banks. Available online: https://johnhcochrane.blogspot.com/2020/10/challenges-forcentral-banks.html (accessed on 12 July 2021).

33. Salter, A.W.; Smith, D.J. End the Fed's Mission Creep. Wall Street Journal. 25 March 2021. Available online: https://www.wsj. com/articles/end-the-feds-mission-creep-11616710463 (accessed on 12 July 2021). 
34. Ozili, P.K. Managing climate change risk: A responsibility for politicians not Central Banks. InNew Challenges for Future Sustainability and Wellbeing; Özen, E., Grima, S., Gonzi, R.E.D., Eds.; Emerald Publishing Limited: Bingley, UK, 2021; pp. 267-276. [CrossRef]

35. Saunders, M.N.; Rojon, C. On the attributes of a critical literature review. Coach. Int. J. Theory Res. Prac. 2011, 4, 156-162. [CrossRef]

36. Stanley, L. The difference between an analytical framework and a theoretical claim: A reply to Martin Carstensen. Pol. Stud. 2012, 60, 474-482. [CrossRef]

37. White, L.H. The Theory of Monetary Institutions; Wiley-Blackwell: Malden, MA, USA, 1999.

38. Tucker, P. Unelected Power: The Quest for Legitimacy in Central Banking and the Regulatory State; Princeton University Press: Princeton, NJ, USA, 2018.

39. Friedman, M.; Goodhart, C.A.E. Money, Inflation and the Constitutional Position of the Central Bank; Institute of Economic Affairs: London, UK, 2003.

40. White, L.H. The rule of law or the rule of central bankers. Cato J. 2010, 30, 451-463.

41. Allen, W.A. Implementing Monetary Policy; Centre for Central Banking Studies, Bank of England: London, UK, 2004.

42. Blinder, A.S. Central Banking in Theory and Practice; MIT Press: Cambridge, MA, USA, 1999.

43. Archer, D.J. A coming crisis of legitimacy? Sver. Riksbank Econ. Rev. 2016, 3, 86-95.

44. Dietsch, P. Legitimacy Challenges to Central Banks: Sketching a Way Forward, Council on Economic Policies Discussion Note 02. 2020. Available online: https:/ / bit.ly/3ss6ESx (accessed on 9 July 2021).

45. Binder, C. De facto and de jure central bank independence. In Populism, Economic Policies and Central Banking; Gnan, E., Masciandaro, D., Eds.; Bocconi University and BAFFI CAREFIN: Wien, Austria, 2020; pp. 129-135.

46. Tortola, P.D. The Politicization of the European Central Bank: What Is It, and How to Study It? JCMS 2020, 58, 501-513. [CrossRef] [PubMed]

47. Rogoff, K. The optimal degree of commitment to an intermediate monetary target. Quart. J. Econ. 1985, 100, 1169-1189. [CrossRef]

48. Best, J. Rethinking central bank accountability in uncertain times. Ethics Int. Aff. 2016, 30, 215-232. [CrossRef]

49. Blinder, A.S. Central-bank credibility: Why do we care? How do we build it? Am. Econ. Rev. 2000, 90, 1421-1431. [CrossRef]

50. Bernanke, B.S. Monetary Policy and Inequality, Brookings. Available online: https://www.brookings.edu/blog/ben-bernanke/ 2015/06/01/monetary-policy-and-inequality/ (accessed on 1 June 2015).

51. Hülsmann, J.G. Fiat money and the distribution of incomes and wealth. In The Fed at One Hundred. A Critical View on the Federal Reserve System; Howden, D., Salerno, J.T., Eds.; Springer International Publishing Switzerland: Heidelberg, Germany, 2014; pp. 127-138.

52. Cœuré, B. Embarking on Public Sector Asset Purchases, Speech Given at the Second International Conference on Sovereign Bond Markets, Frankfurt. 10 March 2015. Available online: https:/ /www.ecb.europa.eu/press/key/date/2015/html/sp150310_1.en. html. (accessed on 6 June 2021).

53. Kane, E.J. Good intentions and unintended evil: The case against selective credit allocation. J. Money Credit Bank. 1977, 9, 55-69. [CrossRef]

54. Volokh, E. The mechanisms of the slippery slope. Harv. Law Rev. 2003, 116, 1026-1137. [CrossRef]

55. Iwasaki, I.; Uegaki, A. Central bank independence and inflation in transition economies: A comparative meta-analysis with developed and developing economies. East. Eur. Econ. 2017, 55, 197-235. [CrossRef]

56. Kokoszczyński, R.; Mackiewicz-Łyziak, J. Central bank independence and inflation-Old story told anew. Int. J. Financ. Econ. 2020, 25, 72-89. [CrossRef]

57. Bagus, P. The ZIRP trap-The institutionalization of negative real interest rates. Procesos Merc. Rev. Eur. Econ. Politica 2015, 12, 105-164.

58. Friedman, M. Comments on monetary policy. Rev. Econ. Stat. 1951, 33, 186-191. [CrossRef]

59. Groepe, F. The Changing Role of Central Banks, Speech given at the University of the Free State, Bloemfontein. Available online: https: / / www.bis.org/review/r160818a.pdf (accessed on 12 August 2016).

60. Mersch, I. Financial Stability and the ECB, Speech Given at the ESCB Legal Conference, Frankfurt a. M. Available online: https:/ / www.ecb.europa.eu/press/key/date/2018/html/ecb.sp180906.en.html (accessed on 6 September 2018).

61. Schnabel, I. When Markets Fail-The Need for Collective Action in Tackling Climate Change, Speech Given at the European Sustainable Finance Summit, Frankfurt a. M. Available online: https://www.ecb.europa.eu/press/key/date/2020/html/ecb.sp2 00928_1 \{\}268b0b672f.en.html (accessed on 28 September 2020).

62. Schnabel, I. From Market Neutrality to Market Efficiency, Speech Given at the ECB DG-Research Symposium Climate Change, Financial Markets and Green Growth, Frankfurt a. M. Available online: https://www.ecb.europa.eu/press/key/date/2021 /html/ecb.sp210614 \{\}162bd7c253.en.html (accessed on 14 June 2021).

63. Schnabel, I. Never Waste a Crisis: COVID-19, Climate Change and Monetary Policy, Speech Given at a Virtual Roundtable on Sustainable Crisis Responses in Europe Organized by the INSPIRE Research Network, Frankfurt a. M. Available online: https: / / www.ecb.europa.eu/press/key/date/2020/html/ecb.sp200717 \{\}1556b0f988.en.html (accessed on 17 July 2020).

64. Feldstein, M. EMU and international conflict. For. Aff. 1997, 76, 60-73. [CrossRef]

65. Bagus, P. The Tragedy of the Euro; Ludwig von Mises Institute: Auburn, AL, USA, 2010.

66. Tesche, T. Instrumentalizing EMU's democratic deficit: The ECB's unconventional accountability measures during the eurozone crisis. J. Eur. Integr. 2019, 41, 447-463. [CrossRef] 
67. Central Bank of Brazil. National Monetary Council. Available online: https://www.bcb.gov.br/en/about/cmnen (accessed on 12 July 2021).

68. Law No. 4,595/31 December 1964 on the National Financial System. Available online: https://bit.ly/3zqFg9K (accessed on 12 July 2021).

69. Central Bank of Brazil. Inflation Targeting. Available online: https://www.bcb.gov.br/en/monetarypolicy/Inflationtargeting (accessed on 12 July 2021).

70. Dall'Orto Mas, R.; Vonessen, B.; Fehlker, C.; Arnold, K. The Case for Central Bank Independence: A Review of Key Issues in the International Debate, ECB Occasional Paper, No. 248, European Central Bank, Frankfurt a. M. 2020. Available online: https:/ /www.econstor.eu/bitstream/10419/234489/1/ecb-op248.pdf (accessed on 12 July 2021).

71. Araújo, E.; Arestis, P. Lessons from the 20 years of the Brazilian inflation targeting regime. Panoeconomicus 2019, 66, 1-23. [CrossRef]

72. Central Bank of Brazil. Social and Environmental Responsibility. Available online: https://www.bcb.gov.br/en/about/ socialresponsibility (accessed on 12 July 2021).

73. Mello, L. Climate Bonds \& Banco Central do Brasil Sign Agreement to Develop Sustainable Finance Agenda: New partnership to share technical knowledge on climate \& financial sector, Climate Bonds Blog. Available online: https://bit.ly/3xYGkBt (accessed on 12 July 2021).

74. Central Bank of Brazil. Sustainability. Available online: https://www.bcb.gov.br/en/financialstability/sustainability (accessed on 12 July 2021).

75. Caminha, M. Brazilian Central Bank opens public consultation on sustainability criteria applicable to rural credit, Climate Bonds Blog. 30 March 2021. Available online: https:/ / bit.ly/2UER9Kn (accessed on 12 July 2021).

76. Law No. 312/28 June 2004 on the Statute of the National Bank of Romania, Monitorul Oficial al României, Part I, No. 582. Available online: https:/ / www.bnro.ro/files/d/Legislatie/Lege_statut_bnr/L_StatBNR.pdf (accessed on 12 July 2021).

77. National Bank of Romania. Direct Inflation Targeting. Available online: https://www.bnr.ro/Direct-Inflation-Targeting-3646.aspx (accessed on 12 July 2021).

78. Isărescu, M. Towards a Green and Smart Economy in Romania. Speech given at the EIB seminar Investment and Investment Finance in Romania, 25 February 2021. Available online: https:/ / bit.ly/3rhbIsl (accessed on 19 July 2021).

79. Organisation for Economic Co-operation and Development. To Green or not to Green? Available online: https:/ /www.oecd.org/ coronavirus/en/themes/green-recovery (accessed on 12 July 2021).

80. National Bank of Romania. Financial Stability Report. June 2020. Available online: https:/ /bnro.ro/DocumentInformation.aspx? idDocument=35334\&idInfoClass=19968 (accessed on 19 July 2021).

81. National Bank of Romania. Inflation Report. May 2021. Available online: https://bnro.ro/DocumentInformation.aspx? idDocument=37236\&idInfoClass=6876 (accessed on 19 July 2021).

82. National Committee for Macroprudential Oversight. Report of the Working Group on Green Finance. Available online: http:// www.cnsmro.ro/res/ups/Raport-CNSM-pentru-sprijinirea-finantarii-verzi_PUB.pdf (accessed on 19 July 2021). (In Romanian).

83. Albulescu, C.T.; Oros, C.; Tiwari, A.K. Oil price-inflation pass-through in Romania during the inflation targeting regime. Appl. Econ. 2017, 49, 1527-1542. [CrossRef]

84. Levieuge, G.; Lucotte, Y.; Ringuedé, S. Central bank credibility and the expectations channel: Evidence based on a new credibility index. Rev. World Econ. 2018, 154, 493-535. [CrossRef] 